Swarthmore College

Works

English Literature Faculty Works

English Literature

Spring 2019

\title{
Lesson Plan For Teaching Colson Whitehead's "The Underground Railroad"
}

Amelia Tomei , '19

Peter Schmidt

Swarthmore College, pschmid1@swarthmore.edu

Follow this and additional works at: https://works.swarthmore.edu/fac-english-lit

Part of the English Language and Literature Commons

Let us know how access to these works benefits you

\section{Recommended Citation}

Amelia Tomei , '19 and Peter Schmidt. (2019). "Lesson Plan For Teaching Colson Whitehead's "The Underground Railroad"'". English Literature Faculty Works. DOI: 10.24968/2476-2458.engl.357

https://works.swarthmore.edu/fac-english-lit/357

\section{(c) (1) (8)}

This work is licensed under a Creative Commons Attribution-Noncommercial 4.0 License

This work is brought to you for free by Swarthmore College Libraries' Works. It has been accepted for inclusion in English Literature Faculty Works by an authorized administrator of Works. For more information, please contact myworks@swarthmore.edu. 


\section{Lesson Plan for Teaching Colson Whitehead's The Underground Railroad}

By Amelia Tomei ’19 / Swarthmore College / Spring 2019

A project completed for Professor Schmidt's

English 052C, “Towards a More Perfect Union: Contemporary U.S. Fiction” / Swarthmore College

Learning Goals: students will...

- Understand how the narrator guides reader's interpretation of the story

- Understand how to read dialogue and how it contributes to characterization

- Explore the complexity of the themes present in the story and the characters Whitehead has created

- Understand how to annotate key references to things outside of the text and apply these back to the main text

\section{Necessary Preparation:}

The teacher should have familiarized him or herself with Whitehead's The Underground Railroad before the first lesson. It is also important that the teacher review definitions of different forms of narration (see below).

This lesson plan is designed to be split into two days of class. 


\section{DAY ONE: Focus on Narrative Technique, Dialogue, and Characterization}

For today the students should have read the first half of Whitehead's novel The Underground Railroad (pp. 1-140). This day, the class will focus around types of narration, dialogue, and characterization. The teacher should begin the class by presenting definitions of the terms below. Then, the class will work together to discuss certain passages focusing on narration and then dialogue and characterization. Discussion questions are provided below for the teacher and should be read in order. The first question should begin discussion and the questions after are follow-up questions. Through analysis of the first half of the novel, the class should arrive together at the purpose of these techniques and devices in portraying key themes. The teacher should write down the key ideas that the class comes up with on the board to compile them.

\section{Narrative Technique}

Before beginning discussion, give a handout or explain the different kinds of third-person narration (see below), answering any questions that may arise. Then, read each passage one at a time and have the class answer the questions below for each passage. The questions will have students identify and discuss the narrative style established in two passages from the novel. For their answers, encourage students to quote from the passage as evidence.

- Third-person "close" narration: the narrator gives a character's thoughts and feelings, but not necessarily in their "voice" while other characters are presented only externally.

- Indirect narration: quoting without quotation marks, using a voice like that of a particular character to give us their thoughts and feelings

- Free indirect narration: using the language of several different people or groups, switching among them; OR paraphrasing the conventional "wisdom" of a group

- Omniscient narration: the narrator knows all the thoughts, actions, and feelings of all characters without focusing on one in particular. It can also whenever it wants give 
perspectives on the story beyond what any of the characters know; it feels "above" or outside of the story-world.

First Passage: "Ajarry bore five children by those men, each delivered in the same spot on the planks of the cabin, which she pointed to when they misstepped. That's where you came from and where I'll put you back if you don't listen. Teach them to obey her and maybe they'll obey all the masters to come and they will survive. Two died miserably of fever. One boy cut his foot while playing on a rusted plow, which poisoned his blood. Her youngest never woke up after a boss hit him in the head with a wooden block. One after another. At least they were never sold off, an older woman told Ajarry. Which was true- back then Randall rarely sold the little ones. You knew where and how your children would die. The child that lived past the age of ten was Cora's mother, Mabel.

Ajarry died in the cotton, the bolls bobbing around her like whitecaps on the brute ocean. The last of her village, keeled over in the rows from a knot in her brain, blood pouring from her nose and white froth covering her lips. As if it could have been anywhere else. Liberty was reserved for other people, for the citizens of the City of Pennsylvania bustling a thousand miles to the north. Since the night she was kidnapped she had been appraised and reappraised, each day waking upon the pan of a new scale. Know your value and you know your place in the order. To escape the boundary of the plantation was to escape the fundamental principles of your existence: impossible.

It was her grandmother talking that Sunday evening when Caesar approached Cora about the underground railroad, and she said no.

Three weeks later she said yes.

This time it was her mother talking" (Whitehead 7-8)

\section{Discussion Questions:}

- Is the passage related in the present or past tense? What is the purpose? When is Cora telling her story?

- Which third-person narration applies to the passage?

- If there are shifts in narration styles, where are they? How do you know shifts are occurring? Why do you think the author chose to include these? 
- How do you think the narrative would change if it were related from a different perspective or perspectives? (such as only first person or omniscient)

- Why do you think the author chose to include Ajarry’s perspective?

Second Passage: "Ridgeway's audience lasted half an hour. He took notes in a small diary and to hear the house speak of it was a man of intense concentration and flowery manner of speech. He did not return for two years, not long before Old Randall's death, to apologize in person for his failure. The Indian was gone, but there was a young rider with long black hair who wore a similar ring of trophies over his hide vest.

Ridgeway was in the vicinity to visit a neighboring planter, offering as proof of capture the heads of two runaways in a leather sack. Crossing the state line was a capital offense in Georgia; sometimes a master preferred an example over the return of his property.

The slave catcher shared rumors of a new branch of the underground railroad said to be operating in the southern part of the state, as impossible as it sounded. Old Randall scoffed. The sympathizers would be rooted out and tarred and feathered, Ridgeway assured his host. Or whatever satisfied local custom. Ridgeway apologized once again and took his leave and soon his gang crashed to the county road toward their next mission. There was no end to their work, the river of slaves that needed to be driven from their hidey-holes and brought to the white man's proper accounting.

Mabel had packed for her adventure. A machete. Flint and tinder. She stole a cabin mate's shoes, which were in better shape. For weeks, her empty garden testified to her miracle. Before she lit out she dug up every yam from their plot, a cumbersome load and ill- advised for a journey that required a fleet foot. The lumps and burrows in the dirt were a reminder to all who walked by. Then one morning they were smoothed over. Cora got on her knees and planted anew. It was her inheritance" (Whitehead 41-42)

\section{Discussion Questions:}

- Which third-person narration applies to the passage? (There are multiple forms of narration in this passage) Encourage students to quote parts of the passage to support their answer

- If there are shifts in narration styles, where are they? How do you know shifts are occurring? Why do you think the author chose to include these? 
- How do you think the narrative would change if it were related from a different perspective or perspectives? (such as only first person or omniscient) Why do you think the author chose this perspective? What does including Ridgeway's perspective add to the novel?

\section{Dialogue and characterization}

The next half of class will be focused on discussion of dialogue and characterization. As a whole class, discuss the passages below. Again, when students are giving answers, encourage them to quote the passages to support their answers.

\section{Passage: "“"Cora."}

Most of the northern half had moved to the kitchen to get fed but Caesar dallied. Here he was. She'd never had occasion to speak to the man since he arrived at the plantation. New slaves were quickly warned against the Hob women. It saved time.

"Can I talk with you?" he asked.

James Randall had bought him and three other slaves from a traveling agent after the fever deaths a year and a half ago. Two women to work the laundry, and Caesar and Prince to join the field gangs. She had seen him whittling, worrying blocks of pine with his curved carving knives. He didn't mix with the more bothersome element on the plantation, and she knew that he sometimes went off with Frances, one of the housemaids. Were they still laying together? Lovey would know. She was a girl, but Lovey kept track of man-and- woman business, the impending arrangements.

Cora felt proper. "What can I do for you, Caesar?"

He didn't bother to see if anyone was in earshot. He knew there was no one because he had planned. "I'm going back north," he said. "Soon. Running away. I want you to come." Cora tried to think of who put him up to this prank. "You going north and I'm going to eat," she said.

Caesar held her arm, gently and insistent. His body was lean and strong, like any field hand his age, but he carried his strength lightly. His face was round, with a flat button nose - she had a quick memory of dimples when he laughed. Why had she kept that in her head? 
"I don't want you to tell on me," he said. "Have to trust you on that. But I'm going soon, and I want you. For good luck."

Then she understood him. It was not a trick being played on her. It was a trick he was playing on himself. The boy was simple. The smell of the raccoon meat brought her back to the celebration and she pulled her arm away. "I ain't trying to get killed by Connelly, or patrollers, or snakes." Cora was still squinting over his idiocy when she got her first bowl of the soup. White man trying to kill you slow every day, and sometimes trying to kill you fast. Why make it easy for him? That was one kind of work you could say no to" (Whitehead 26-27)

\section{Discussion Questions:}

- How should we read the dialogue in this scene?

- How does the dialogue alone characterize Cora?

- Does that change when her thoughts are given (last paragraph of the passage)?

- How does the dialogue characterize Caesar?

- What do you think is left unsaid (no spoilers)?

- How can we guess that there's more going on than what is said aloud (by both Cora and Caesar)?

- How does this conversation influence Cora later in the novel? Does it influence certain actions?

\section{Passage: "“"Bessie?"}

“Good evening, Miss Lucy,” Bessie said.

It was rare Miss Lucy stayed this late on a Friday. Most proctors disappeared at six o'clock. To hear the girls from the other dormitories tell it, Miss Lucy's diligence put her colleagues to shame. To be sure, Bessie had benefited from her advice many times. She admired the way her clothes were always so crisp and fit just so. Miss Lucy wore her hair in a bun and the thin metal of her eyeglasses lent her a severe aspect, but her quick smile told the story of the woman beneath.

"How are things?" Miss Lucy asked.

“Think I'm gonna spend a quiet night in the quarter, Miss Lucy,” Bessie said.

"Dormitory, Bessie. Not quarter."

"Yes, Miss Lucy." 
"Going to, not gonna"

"I am working on it."

“And making splendid progress!” Miss Lucy patted Bessie’s arm. "I want to talk to you Monday morning before you head out for work."

"Anything wrong, Miss Lucy?"

"Nothing at all, Bessie. We'll talk then." She gave a little bow and walked to the office.

Bowing to a colored girl" (Whitehead 89)

\section{Discussion Questions:}

- How should we read the dialogue in this scene?

- How does the dialogue characterize Bessie and Miss Lucy?

- Is the description of Miss Lucy an objective description, or from someone's point of view?

- If the description of Miss Lucy was omitted, would you read her character differently?

- To what extent does this interaction help influence Cora's decision to stay in South Carolina (until she is forced to leave)?

- Why does Miss Lucy insist that Bessie use the word dormitory rather than quarter? Why do you think that "Bessie" chose the word quarter, and how did she mean it? Why was she corrected? (There's an irony here relevant to the previous question.)

Passage: "The physical examination was not as extensive as the first. He consulted the records from her previous visit and added his own notes on blue paper. In between he asked her about dormitory life. "Sounds efficient," Dr. Stevens said. He declared the museum work "an intriguing public service."

After she dressed, Dr. Stevens pulled over a wooden stool. His manner remained light as he said, "You've had intimate relations. Have you considered birth control?"

He smiled. South Carolina was in the midst of a large public health program, Dr. Stevens explained, to educate folks about a new surgical technique wherein the tubes inside a woman were severed to prevent the growth of a baby. The procedure was simple, permanent, and without risk. The new hospital was specially equipped, and Dr. Stevens himself had studied under the man who pioneered the technique, which had been perfected on the colored inmates of 
a Boston asylum. Teaching the surgery to local doctors and offering its gift to the colored population was part of the reason he was hired.

"What if I don't want to?"

"The choice is yours, of course," the doctor said. "As of this week, it is mandatory for some in the state. Colored women who have already birthed more than two children, in the name of population control. Imbeciles and the otherwise mentally unfit, for obvious reasons. Habitual criminals. But that doesn't apply to you, Bessie. Those are women who already have enough burdens. This is just a chance for you to take control over your own destiny."' (Whitehead 113)

\section{Discussion Questions:}

- How should we read the dialogue in this scene?

- How does this passage characterize Stevens (think about his tone)?

- What role does Dr. Stevens play in the exploitation of blacks?

- What does Cora's statement "What if I don't want to?" say about her character? (think about the tone here as well)

- Why would the author choose to use indirect narration in the middle of the passage? What does it add or take away?

- Is there more going on than what is being said aloud? If so, what?

- What does the irony of Cora being able to "choose her own destiny" add to the passage and novel as a whole?

\section{DAY TWO: Focus on Themes}

For today the students should have read the second half of Whitehead's novel The Underground Railroad. This day, the class will focus around some of the themes present in the novel: Family, Heritage, and Home; Endurance vs. Rebellion; Death and Freedom. Students should also be encouraged to build on their discussions from the day before by discussing the purpose of narration and dialogue. 
The teacher should begin by presenting the themes that will be discussed. Then, the teacher should split the class into groups based on each theme. The teacher may decide whether the groups are assigned or not. Again, the questions should be asked and answered in order. Once $\sim 25$ minutes are remaining, the teacher will call everyone's attention back together and each group will have an opportunity to present material and passages they talked through and other students will have an opportunity to make comments on these ideas. The last $\sim 10$ minutes of class will be spent explaining the research project (more details below).

\section{Family, Heritage, and Home}

1. "It was her grandmother talking that Sunday evening when Caesar approached Cora about the underground railroad, and she said no.

Three weeks later she said yes.

This time it was her mother talking" (Whitehead 8)

Discussion Questions: In what ways did Mabel influence Cora's escape? Why would Cora run away like her mother did if Cora hates her mother for abandoning her to a life of captivity? Is it accurate to say that running away and pursuing freedom is her family "inheritance"?

2. Cora's little plot/garden: "The dirt at her feet had a story, the oldest story Cora knew" (Whitehead 12). And in another instance, "The lumps and burrows in the dirt were a reminder to all who walked by. Then one morning they were smoothed over. Cora got on her knees and planted anew. It was her inheritance" (41-42)

Discussion Questions: What does the garden symbolize? What is the significance of the garden? How is this lineage of freedom between mother and daughter is further underlined by the garden? [Note: this moment may a tribute to/inspired by the ideas in Alice Walker's very influential In Search of Our Mothers Gardens.]

3. "Ethel thought that a slave was someone who lived in your house like family but was not family. Her father explained the origin of the negro to disabuse her of this colorful idea. Some maintained that the negro was the remnant of a race of giants who had ruled the 
earth in an ancient time, but Edgar Delany knew they were descendants of cursed, black Ham, who had survived the Flood by clinging to the peaks of a mountain in Africa. Ethel thought that if they were cursed, they required Christian guidance all the more" (Whitehead 192)

Discussion Questions: How does this passage characterize Ethel and her father? How do they compare to other white people Cora encounters in the novel? How does this represent the ways in which family, kinship, and heritage are distorted by the institution of slavery? (Think about the tone and diction used in this passage) How does this influence Ethel's later actions? How does this highlight the way in which enslaved people live among whites?

4. "He left Virginia, he said, to spare his children the ravages of prejudice and its bully partner, violence. But saving two children is not enough when God has gifted you with so much. "A woman came to us out of the bitter winter-sick and desperate. We could not save her." Valentine's voice rasped. "I neglected my duty. As long as one of our family endured the torments of bondage, I was a freeman in name only. I want to express my gratitude to everyone here for helping me to put things right. Whether you have been among us for years or just a few hours, you have saved my life."' (Whitehead 282-283) Discussion Questions: Why would the author include indirect narration and direct quotation? How do these characterize Valentine? Who is the family he is referring to here? What does the novel suggest about a feeling of kinship and solidarity among people of African descent who are living in America? Is kinship necessary for survival? What about looking out for one's own self-interests? Does the novel portray one or the other as more important? If so, how? [Think of Cora and her actions.]

5. "Ridgeway spat tobacco juice on the sidewalk, at the feet of some onlookers. "You can keep the reward," he told Fiona. He bent slightly and lifted Cora by her arm. "You don't have to be afraid, Cora. You're going home."' (Whitehead 187).

Discussion Questions: How does this dialogue characterize Ridgeway? What does Randall represent? What is the definition of a "home"? To what extent can Randall be considered a home?

6. "Ending her day in Scenes from Darkest Africa never failed to cast her into a river of calm, the simple theater becoming more than theater, a genuine refuge" (Whitehead 125). 
Discussion Questions: Is Africa more of a home than Randall? Why or why not? What is Cora's true home, if neither Randall nor "Africa" are? Is it any particular location? Or something else? How does slavery distort the definition of "Home"?

\section{Endurance vs. Rebellion}

1. "Since the night she was kidnapped she had been appraised and reappraised, each day waking upon the pan of a new scale. Know your value and you know your place in the order. To escape the boundary of the plantation was to escape the fundamental principles of your existence: impossible" (Whitehead 8).

Discussion Questions: How does this passage characterize Ajarry? What made Ajarry think that escape was impossible, while her daughter and granddaughter did not? What other minor forms of rebellion does Ajarry use instead?_[Ajarry is neither passive nor mentally enslaved. Yet indirect narration here in the last sentence describes what seems very like Ajarry’s own despairing thoughts.]

2. "White man trying to kill you slow every day, and sometimes trying to kill you fast. Why make it easy for him? That was one kind of work you could say no to" (Whitehead 27). Discussion Questions: What kind of narration is used here? How does it add to our understanding of Cora and her character? Why does Cora view enduring slavery as the only way she can exercise autonomy? What observations may have led to this? What made her change her mind? Does she really change her mind? (Would she have died faster on Randall with new owners or was it something else?)

3. 'Off to Hob with those who had been crippled by the overseers' punishments, off to Hob with those who had been broken by the labor in ways you could see and in ways you could not see, off to Hob with those who had lost their wits. Off to Hob with strays" (Whitehead 16).

When Caesar asks her to escape with him, Cora thinks of the idea as a "prank," "a trick he was playing on himself," and "idiocy." (27)

Discussion Questions: What do these quotes imply about those who decided to escape? To what extent does Cora fit in the Hob? Did Cora's placement in the Hob have an influence on her decision to escape? How? To what extent did being placed in the Hob 'free' her? 
4. "Terrance Randall provided a model for a mind that could conceive of North Carolina's new system, but the scale of the violence was hard to settle in her head. Fear drove these people, even more than cotton money. The shadow of the black hand that will return what has been given. It occurred to her one night that she was one of the vengeful monsters they were scared of: She had killed a white boy. She might kill one of them next. And because of that fear, they erected a new scaffolding of oppression on the cruel foundation laid hundreds of years before. That was Sea Island cotton the slaver had ordered for his rows, but scattered among the seeds were those of violence and death, and that crop grew fast. The whites were right to be afraid. One day the system would collapse in blood" (Whitehead 172)

Discussion Questions: How does rebellion occupy the mind of white-slave owners and their allies? Who/what kind of narrator is being used here? Is the narrator accurate in their depiction of the white people in North Carolina? Why do those in South Carolina act differently? Do they act differently at all? To what extent do white people who help Cora differ in their opinions of rebellion from white slave owners and their allies? (try to bring up textual evidence). Note also the reference here to the fact that Cora has clearly emerged from underground into a "space" or geography in continual American racial history that cannot be simply located in $1820-40$ or so.

5. "The specter of colored rebellion, all those angry dark faces surrounding them, had stirred white settlers to leave the south." (Whitehead 249).

Discussion Questions: How are white people who fled to the north different from those staying in the south? Are they different at all? What message is being sent about the majority of white people in the novel? Note also how the sentence uses free indirect to give the whites' voice and perspective re "them". "Specter of colored rebellion" could be (and probably is) a clichéd and revealing phrase Whitehead "borrowed" from the reams of $19^{\text {th }}$ century documents he read to research the book.

6. "Once Mabel ran, Cora thought of her as little as possible. After landing in South Carolina, she realized that she had banished her mother not from sadness but from rage. She hated her. Having tasted freedom's bounty, it was incomprehensible to Cora that Mabel had abandoned her to that hell. A child. Her company would have made the escape more difficult, but Cora hadn't been a baby. If she could pick cotton, she could run. She 
would have died in that place, after untold brutalities, if Caesar had not come along" (Whitehead 98)

Discussion Questions: How did Mabel's rebellion lead to Cora's escape? Was Mabel's rebellion really selfish, or did it have another purpose? As a whole, what does the novel imply about rebellion and resistance? What are the long-term effects of small acts of resistance as shown in the novel (the garden, escape, etc)?

\section{Death and Freedom}

1. "Every slave thinks about it. In the morning and in the afternoon and in the night. Dreaming of it. Every dream a dream of escape even when it didn't look like it" (Whitehead 56).

Discussion Questions: Why do slaves dream of freedom even if they never even consider trying to escape? What does this imply about dreams? What connection do dreams have to freedom?

2. "“'Jesus, carry me home, home to that land..." Jasper wouldn't stop singing. Ridgeway shouted from the head of their little caravan for him to shut his mouth, and sometimes they halted so Boseman could climb into the wagon and clout the runaway on the head. Jasper sucked the scars on his fingers for a short interval, then resumed his crooning. Quietly at first so that only Cora could hear. But soon he'd be singing again, to his lost family, to his god, to everyone they passed on the trail. He'd have to be disciplined again" (Whitehead 199).

Later Cora says, "He's not eating" (201)

Discussion Questions: How do these passages characterize Cora and Jasper? Who/what is the narrator? How is religion a form of freedom or escape? Why would Jasper stop eating in an attempt to kill himself? What is the connection between freedom, death, and religion?

3. "The corpses hung from trees as rotting ornaments..."They call this road the Freedom Trail now," Martin said as he covered the wagon again. "The bodies go all the way to town.", (Whitehead 152-153).

Discussion Questions: What is the purpose of the "Freedom trail"? How does the name 
suit its purpose and makeup? What does this trail imply about those who escape and do not make it on the Freedom trail?

4. "White man trying to kill you slow every day, and sometimes trying to kill you fast. Why make it easy for him? That was one kind of work you could say no to" (Whitehead 27) Discussion Questions: What kind of narration is used here? How does it add to our understanding of Cora and her character? How is life on the plantation related to death? How does escape relate to this? To what extent are death and freedom the same?

5. "The snake found her not long into her return. She was wending through a cluster of stiff reeds when she disturbed its rest. The cottonmouth bit her twice, in the calf and deep in the meat of her thigh. No sound but pain. Mabel refused to believe it. It was a water snake, it had to be. Ornery but harmless. When her mouth went minty and her leg tingled, she knew. She made it another mile. She had dropped her sack along the way, lost her course in the black water. She could have made it farther-working Randall land had made her strong, strong in body if nothing else-but she stumbled onto a bed of soft moss and it felt right. She said, Here, and the swamp swallowed her up" (Whitehead 294295)

Discussion Questions: What kind of narration is used here? Why? How would it be different if this story was told to another character? What is the significance of only the reader knowing about Mabel's death? Why is it important for the reader to know that Mabel died? Why would it be placed almost at the end of the novel? How does her escape encourage Cora? Would she have escaped if she knew about Mabel's death?

6. “"Liberty make a body fertile," Georgina said. That, and the knowledge they will not be sold, Cora added. The women in the colored dormitories of South Carolina believed they knew liberty, but the surgeons' knives cut them to prove otherwise" (Whitehead 246) Elsewhere, the narrator remarks: "Because that's what you do when you take away someone's babies-steal their future" (117).

Discussion Questions: What do these statements imply about free black people? How do these statements relate to death? To what extent is having no future/cutting a family line the same as death? What does the novel imply about black people in their search for freedom? Is there any way to escape death in their search? To what extent is it an 
inevitable part of their journey, whether for themselves or for those around them? (Think of examples in Cora's journey)

\section{$\underline{\text { Research Project }}$}

Students will be assigned a short paper (4-5 pages long) on the story. In it, they must discuss 1-2 key references to things outside of the text (citations of events or ideas, allusions to people or works of art, music, or literature, etc.). It is up to the teacher to decide whether this assignment be a full-fledged paper with an introduction, thesis, and conclusion and a reading of the novel as a whole or a shorter assignment. If a full paper, students should be able to apply some of the themes they discussed in class or another they have found during their discussions. If not a full paper, students should conclude their paper with brief reflections on how this task may yield insights about how the novel works as a whole and what they learned from this task. Students should answer the following question in their response: How does your new information help us read this moment in the book, and perhaps the book as a whole?

When giving this assignment, the teacher should explain what it means to annotate:

Annotate means not just tracking down a reference or two but evaluating it and then applying it intelligently to generate a brief reading.

In addition, there are several guidelines students should follow when conducting research and utilizing it in their paper.

- Students should evaluate their source for accuracy, especially if it's on the internet. Recommend students to check out several sources for comparison.

- Tell students to make sure they cite at the end of the paper ALL sources used, whether print or online. 
- Students should not quote an entire dictionary entry, encyclopedia entry, etc. and only include relevant information.

- When considering annotations to include, they should make sure that it applies strongly towards interpreting the primary text. The best annotations give the reader an unexpected and useful insight about an allusion or reference so that it deepens their understanding of the text.

Some possible references/allusions students may find include: The Museum of Natural Wonders, the Tuskegee Syphilis Experiment, lynchings, the Freedom Road, the spread of yellow fever, the philosophy of Manifest Destiny, and Gulliver's Travels by Jonathan Swift. The teacher should familiarize themselves with some of these references if they have not already.

\section{Discussion of the Lesson Plan}

The objectives stated in the lesson plan cover a number of skills that students are expected to gain or employ during the class and in the completion of reading and homework assignments. Some of these goals are specific and content-related, while others focus on the development of broader abilities. First are the objectives related to learning the different forms of third-person narration. It is important that students not only learn the definitions of these different narrative forms but that they are able to see them applied and that they learn to recognize them in writing. It is also useful to for them to learn how these narrative forms can add to the story. The story is used in this lesson to illustrate the use of these narrative forms so that they do not remain vague and abstract ideas.

Second are the goals relating to dialogue and characterization. While many students may learn about these concepts on a basic level, many do not know how to apply these concepts together and see how these add to the overall story. It is important for students to not only recognize dialogue and characterization, but to see how dialogue affects characterization. Also, 
in many cases, students will discuss what is said in the passage, but in order to improve critical thinking and analyses skills, students should be able to discuss what is left unsaid and why. There are many complex and unique characters in this novel, providing the perfect framework to build these skills and analyze dialogue and characterization.

Once students have reached the first two learning goals for the first day on this novel, they should be able to reach the third learning goal on the second day. As mentioned above, discussing the concepts of narration, dialogue, and characterization will help build a student's critical thinking and analysis skills. Therefore, they will be prepared to discuss the complex themes present in the novel. While there are many themes present in the novel, the three chosen-Family, Heritage, and Home; Endurance vs. Rebellion; and Death vs. Freedom—are some of the most prevalent in the novel, and students will have likely already discussed or thought about these themes on the first day of discussion or while reading. In addition, students can further practice the skills they learned on day one to discuss these themes.

The last learning goal is especially important for this novel. Students will have likely already noticed the extensive amount of references and allusions in this novel. These allusions are essential to the novel and the message it sends about the state of black people in America. Therefore, the lesson would not be complete without having students explore some of these references on their own where they can not only further practice their critical thinking and analysis skills, but applying specific concepts and ideas_(like narration, dialogue, and characterization) to the reading of a certain passage and the novel as whole. This assignment was created as an individual, take-home writing assignment so that students would have enough time to research topics they may be interested and think about how to apply their findings to their reading of the text. 
In terms of the format of the lessons, I chose a combination of lecture style/class discussion with small group discussion. The first lesson requires a large amount of teacher led discussion since the terms presented may be new or unfamiliar to students, so the teacher needs to be available to everyone to explain these and answer questions. By the second lesson, students will already be familiar and comfortable with these terms and how to discuss them. Students generally feel more comfortable voicing their opinions in smaller groups and the contained nature of the discussion allows them to reply to each other's ideas without having to wait for a turn to speak, encouraging them to engage in thought-provoking discussion grounded on critical thinking. Additionally, it provides them the flexibility to explore interesting avenues of thought that might seem tangential in a whole-class discussion. Therefore, small group discussions will allow more students to discuss the novel with others than in a larger class, especially if they are more comfortable speaking with less people.

When I was making this lesson plan, I found making good questions was particularly difficult. I wanted students to think about how the narrator influenced their interpretation of the text, but I didn't want to ask leading questions that made the answers obvious. I eventually tried to solve the problem by asking more broad questions. I also thought about how I would respond if a teacher asked me that question in class. I wanted multiple answers to be possible and I tried

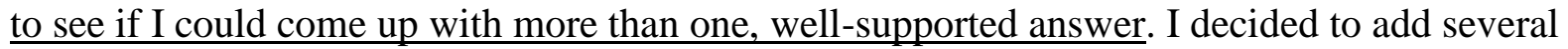
follow up questions that could further discussion. I also asked them to my friends who were around me and incorporated their feedback into my lesson plan.

I also struggled with deciding what passages to include for discussion. I wanted to include those that were not only useful in discussing dialogue, narrative techniques, and characterization, but also those that included some of the themes students would discuss on day 
two. While there is some overlap, I realized that it would be impossible to include every important passage. Therefore, I decided that teachers should encourage students, when making conclusions on the book as a whole, to cite textual evidence from other parts of the novel. In addition, I thought that including an activity where the students get to explore other parts of the novel on their own will allow them to discuss in depth parts of the novel that may have not been discussed in class.

Through this process, I learned that teaching requires thinking from multiple perspectives. I had to keep instructor in mind when I was writing explanations for including certain lessons and questions because I wanted them to understand the reasoning behind my decisions for the lesson, but I also had to consider students' positions when formulating questions. And sometimes, such as when I was picking learning goals and structuring my lesson plan, I had to think about both parties: would teachers want to cover this material, and would students want to learn it/be able to reach those goals? This required more mental flexibility than I thought it would and although it was difficult at times, I feel that I now have a better understanding of how information and ideas flow between student and teacher. 